\title{
Systematic approach for the development of fruit wines from industrially processed fruit concentrates, including optimization of fermentation parameters, chemical characterization and sensory evaluation
}

\author{
Eduardo Coelho ${ }^{a}$, Mar Vilanova $^{\mathrm{b}}$, Zlatina Genisheva ${ }^{\mathrm{a}}$, José M. Oliveira ${ }^{\mathrm{a}}$, José A. Teixeira ${ }^{\mathrm{a}}$, \\ Lucília Domingues ${ }^{a}$ *
}

${ }^{a}$ CEB - Centre of Biological Engineering, University of Minho, 4710-057, Braga, Portugal

${ }^{\mathrm{b}}$ Misión Biológica de Galicia - CSIC, PO Box 28, 38080 Pontevedra, Spain

\section{A R T I C L E I N F O}

\section{Article history:}

Received 9 October 2014

Received in revised form

5 February 2015

Accepted 15 February 2015

Available online 24 February 2015

\section{Keywords:}

Alcoholic fermentation

Mathematical modelling

Antioxidant activity

Chemical-sensory correlation

\begin{abstract}
A B S T R A C T
This work presents an optimized approach alongside with the mathematical models describing the production of fruit wines, using fruit concentrates as an alternative to attain the desired ethanol yields and enhance organoleptic and functional properties. Box-Behnken design was used for modeling and optimization of ethanol yield and productivity in banana, orange, cherry and mango concentrates fermentations. Optimization allowed ethanol yields of $72.3 \pm 2.08 \mathrm{~g} \cdot \mathrm{L}^{-1}$ in orange, $101 \pm 1.78 \mathrm{~g} \cdot \mathrm{L}^{-1}$ in mango, $66.1 \pm 4.02 \mathrm{~g} \cdot \mathrm{L}^{-1}$ in cherry and $98.2 \pm 7.88 \mathrm{~g} \cdot \mathrm{L}^{-1}$ in banana with maximal productivities of $0.4 \pm 0.0 \mathrm{~g} \cdot \mathrm{L}^{-1} \cdot \mathrm{h}^{-1}, 1.0 \pm 0.1 \mathrm{~g} \cdot \mathrm{L}^{-1} \cdot \mathrm{h}^{-1}, 1.7 \pm 0.2 \mathrm{~g} \cdot \mathrm{L}^{-1} \cdot \mathrm{h}^{-1}$ and $1.0 \pm 0.1 \mathrm{~g} \cdot \mathrm{L}^{-1} \cdot \mathrm{h}^{-1}$, respectively. Evaluation of total antioxidant activity by FRAP demonstrated fruit wines potential for the development of foods and formulations with functional properties, attaining $22.6 \pm 0.46 \mathrm{mmol} \cdot \mathrm{L}^{-1}$ for orange, $7.14 \pm 0.77 \mathrm{mmol} \cdot \mathrm{L}^{-1}$ for mango, $28.0 \pm 1.84 \mathrm{mmol} \cdot \mathrm{L}^{-1}$ for cherry and $9.54 \pm 0.89 \mathrm{mmol} \cdot \mathrm{L}^{-1}$ for banana wines. Characterization of aroma active compounds was performed by GC-MS and sensory evaluation by trained panelists. All fruit wines had good acceptance with cherry wine presenting the highest overall preference, followed by orange, mango and banana wines. Correlation between chemical and sensory properties was established with PLSR2 between analytical and sensory data, which allowed an insight of chemical composition impact in consumer perceived quality.
\end{abstract}

๑ 2015 Elsevier Ltd. All rights reserved.

\section{Introduction}

Fruit is one of the main sources of diversity for food formulations. Besides providing flavors, aromas and colors, some are also rich in dietary fiber, vitamins and phenolic compounds, with functional properties advantageous for food design (Müller, Gnoyke, Popken, \& Bröhm, 2010). However, fruit possess limited shelf-life, causing product losses and spoilage, which can be amplified by quality regulation, where pieces that do not fulfill the desired morphological requisites are not suitable for direct distribution (Gustavsson, Cederberg, Sonesson, Otterdijk, \& Meybeck, 2011). Alcoholic fermentation is highly acknowledged in the beverage industry,

\footnotetext{
* Corresponding author. Tel.: +351 253 604402; fax: +351 253604429

E-mail address: luciliad@deb.uminho.pt (L. Domingues).
}

generating less perishable value added products, such as wine and beer (Caplice \& Fitzgerald, 1999). Besides conservation, fermentation has impact on secondary metabolites, transforming organoleptic properties and differentiating products (Ribéreau-Gayon, Glories, Maujean, \& Dubourdieu, 2006). Furthermore, alcoholic fermentation can generate added-value products by further processing, such as vinegars, spirits and food ingredients. One concern regarding alcoholic beverages is their health impact, being the type of beverage and patterns of consumption extremely important when focusing consumer concerns. Patterns of excessive consumption are widely acknowledged by their strong negative effects on human and public health (Room, Babor, \& Rehm, 2005). On the other hand, beneficial effects of moderate drinking have been reported, such as lower risk of cardiovascular diseases (Artero, Artero, Tarín, \& Cano, 2015), lower risk of type 2 diabetes (Koppes, Dekker, Hendriks, Bouter, \& Heine, 2005) and reducing cognitive function 
losses (Neafsey \& Collins, 2011). Recent efforts have been made to create alcoholic beverages from fruit, as recently reported for fruit wastes re-valorization (Isitua \& Ibeth, 2010). Moreover, experimental approaches for the production of cherry (Sun et al., 2013) and orange (Santos, Duarte, Carreiro, \& Schwan, 2013) spirits were recently reported, focusing on the beverages sensory quality. Some of these works included strategies such as enzymatic hydrolysis, sucrose addition or post fermentation distillation to compensate low fermentable sugar concentration and attain the desired ethanol yield. As an alternative, this work resorts to fruit concentrates for sugar concentration and increase of ethanol yield, concentrating also taste, aroma and functional features to generate a wine grade product, suitable for multiple applications. A systematic approach was carried out focusing on mathematical modeling and optimization of fermentation parameters to maximize ethanol production and productivity. Fruit wines were characterized to establish chemical-sensorial correlations and assess acceptability. Their functional potential was evaluated, with quantification of antioxidant activity, providing further added-value to fruit wines as food grade products.

\section{Materials and methods}

\subsection{Chemicals}

The following chemicals were used for the standards: citric acid monohydrate (99.5\%) (Merck), absolute ethanol (99.5\%) (Panreac), L(-)- Malic Acid (99\%) (Acros Organics), $\alpha$-D-Glucose (96\%) (Aldrich Chemistry), $\mathrm{D}(-)$ - Fructose (99\%) (Acros Organics), D(+)-Saccharose (99\%) (Fisher Scientific) and Iron (II) Sulfate Heptahydrate (99\%) (Acros Organics). For the FRAP assay: 2,4,6-Tris(2-pyridyl)-striazine ( $\geq 98 \%$ ), Iron (III) chloride $(>97 \%)$ and Sodium Acetate ( $\geq 99 \%$ ), all from Sigma-Aldrich. For GC-FID the following standards were used: acetaldehyde ( $\geq 99.5 \%)$, methyl acetate $(\geq 99.9 \%$ ), 1-propanol ( $\geq 99.9 \%)$, 2-methyl-1-propanol ( $\geq 99.8 \%)$, 2-methyl-1butanol ( $\geq 98 \%$ ), 3-methyl-1-butanol ( $\geq 99.8 \%)$, 2,3-butanediol, levo ( $\geq 99.0 \%$ ), 2,3-butanediol, meso ( $\geq 99.0 \%$ ), 2-phenylethanol $(\geq 99.0 \%$ ) from (Fluka) and ethyl acetate (99.8\%), methanol ( $\geq 99.8 \%$ ), diethyl succinate $(99.0 \%$ ) from (Sigma-Aldrich). For GC-MS calibration: 1-hexanol ( $\geq 99.9 \%$ ), Z-3-hexenol ( $\geq 98 \%$ ), 1octanol ( $\geq 99.5 \%)$, furfuryl alcohol ( $\geq 98 \%)$, isobutyl acetate ( $\geq 98.5 \%$ ), 2-phenylethyl acetate ( $\geq 99.0 \%$ ), fenchol ( $\geq 99.0 \%$ ), borneol (>95.0\%), trans-furan linalool oxide and cis-furan linalool oxide ( $\geq 97.0 \%)$, propanoic acid $(\geq 99.5 \%)$, isobutyric acid $(\geq 99.5 \%)$, butyric acid ( $\geq 99.5 \%$ ), hexanoic acid $(\geq 98.0 \%$ ), decanoic acid ( $\geq 98.0 \%$ ), benzaldehyde ( $\geq 99.0 \%$ ) from Fluka, 3-ethoxy-1-propanol (97\%), benzyl alcohol ( $\geq 99.0 \%)$, 2-phenoxyethanol (98.0\%), ethyl butyrate (99.0\%), 3-methylbutyl acetate ( $\geq 99.0 \%$ ), ethyl hexanoate ( $\geq 99.9 \%)$, Z-3-hexenyl acetate $(\geq 98 \%$ ), ethyl octanoate $(\geq 99.0 \%)$, ethyl 3-hydroxybutyrate (99.0\%), ethyl decanoate ( $\geq 99.0 \%)$, benzyl acetate ( $\geq 99.0 \%$ ), linalool (97\%), terpinen-4-ol ( $\geq 99.0 \%)$, citronellol (95\%), nerol (97\%), geraniol (98\%), eugenol (99\%), 4-vinylguaiacol ( $\geq 98 \%$ ), 4-vinylphenol (12\%), acetovanillone (98\%), zingerone ( $\geq 96 \%), \quad 3,4,5$-trimethoxyphenol (97\%), 3-methyl +2 methylbutyric acids (99\%), octanoic acid ( $\geq 99.5 \%)$, methoxyfuraneol ( $\geq 97 \%)$, furaneol ( $\geq 98 \%), \quad \gamma$-decalactone $(\geq 98 \%)$, 2methyltetrahydrothiophen-3-one ( $\geq 97 \%)$, 2-(methylthio)ethanol (99\%), methionol (98\%), 6-methyl-5-hepten-2-one (99\%) from Sigma-Aldrich, isopulegol I (>85.0\%) from TCI, myrcenol $(\geq 90.0 \%)$ from Ventós and $\alpha$-terpineol ( $\geq 98.0 \%$ ) from Merck.

\subsection{Characterization of fermentable sugars in the fruit concentrates}

Fermentable sugars were quantified by HPLC using a Varian Metacarb $87 \mathrm{H}$ column, $\mathrm{H}_{2} \mathrm{SO}_{4} 5 \mathrm{mmol} \cdot \mathrm{L}^{-1}$ as mobile phase at
$0.5 \mathrm{~mL} \cdot \mathrm{min}^{-1}$ and oven temperature of $35^{\circ} \mathrm{C}$ to prevent sucrose hydrolysis. Sugars were measured using a Jasco RI-1530 detector and quantified with the proper calibration curves. Total fermentable sugar concentration was calculated by sum of fermentable sugars concentration, namely sucrose, glucose and fructose.

\subsection{Fruit mashes preparation}

Four whole, non-clarified, industrial fruit concentrates were used, kindly provided by Frulact S.A. (Maia, Portugal) with ${ }^{\circ}$ Brix, $\mathrm{pH}$ and processing presented in Table 1.

\subsection{Alcoholic fermentations}

Musts were prepared diluting fruit mash with sterile water to the desired initial ${ }^{\circ} \mathrm{Brix}\left(B_{i}\right)$, followed by pH correction to 4.5 using $5 \mathrm{~mol} \cdot \mathrm{L}^{-1} \mathrm{NaOH}$. Alcoholic fermentation was conducted in Erlenmeyer flasks with glycerol lock, ensuring anaerobic conditions and $\mathrm{CO}_{2}$ exhaustion. Musts were inoculated with lyophilized oenological yeast Lalvin QA23 (Lallemand), incubated with temperature control, orbital agitation of $150 \mathrm{~min}^{-1}$ and monitored by weight loss measurement, equivalent to $\mathrm{CO}_{2}$ production and exhaustion, for stationary phase determination. Ethanol concentration $\left(\mathrm{C}_{\mathrm{EtOH}}\right)$ was quantified by HPLC, and productivity $(P)$ was calculated dividing $C_{E t O H}$ by stationary phase entry time.

\subsection{Factorial design}

Ethanol yield and productivity were mathematically modeled using Box -Behnken design, to evaluate dependent variables (ethanol concentration $\left(\mathrm{C}_{\mathrm{EtOH}}\right)$ and productivity $(\mathrm{P})$ ) response to fermentation parameters, namely must initial ${ }^{\circ} \mathrm{Brix}\left(B_{i}\right)$, temperature $(T)$ and inoculum concentration $\left(C_{\text {inoc }}\right)$. Box-Behnken design was outlined with 3 independent variables and triplicates in the central point, generating the experiments represented in Table 2 , where the independent variables are expressed in dimensional and adimensional parameters. For the optimization, mathematical models were converged for determination of optimal fermentation conditions and responses, using StatGraphics Plus software (Version 5.1, Statistical Graphics corp.). After optimization, a validation assay was conducted to determine models accuracy.

\subsection{Chemical characterization of fruit wines}

\subsubsection{Ethanol concentration and organic acid composition}

Ethanol and organic acids were measured by HPLC, using a Varian Metacarb $87 \mathrm{H}$ column using $\mathrm{H}_{2} \mathrm{SO}_{4} 5 \mathrm{mmol} \cdot \mathrm{L}^{-1}$ mobile phase at a $0.7 \mathrm{~mL} \cdot \mathrm{min}^{-1}$ flow. Organic acids were measured using a Jasco 870-UV detector (210 $\mathrm{nm}$ wavelength) and ethanol was

Table 1

Brix degree $\left({ }^{\circ} \mathrm{B}\right)$, initial $\mathrm{pH}$ and fruit mash processing steps, of the fruit concentrates used for must preparations and fermentation.

\begin{tabular}{|c|c|c|c|}
\hline Mash & ${ }^{\circ} \mathrm{B}\left({ }^{\circ} \mathrm{Brix}\right)$ & Initial $\mathrm{pH}$ & Processing \\
\hline Comminuted Orange & 40.0 & $3.8 \pm 0.1$ & $\begin{array}{l}\text { Whole crunched, heated, chilled } \\
\text { and packed }\end{array}$ \\
\hline Mango puree & 28.0 & $3.8 \pm 0.1$ & $\begin{array}{l}\text { Mashed, fine sieved, concentrated, } \\
\text { pasteurized and packed }\end{array}$ \\
\hline Sour Cherry puree & 32.0 & $3.4 \pm 0.3$ & $\begin{array}{l}\text { Mashed, fine sieved, concentrated, } \\
\text { pasteurized and packed }\end{array}$ \\
\hline Banana puree & 31.5 & $4.4 \pm 0.2$ & $\begin{array}{l}\text { Peeled, mashed, acidified, } \\
\text { homogeneized, deaerated, } \\
\text { concentrated, pasteurized and } \\
\text { packed }\end{array}$ \\
\hline
\end{tabular}


Table 2

Box-Behnken experimental planning included process parameters studied (initial Brix degree $\left(B_{i}\right)$, Temperature $(T)$ and Inoculum concentration $\left(C_{\text {inoc }}\right)$ ), expressed in terms of adimensional and corresponding dimensional values (between brackets).

\begin{tabular}{|c|c|c|c|c|c|}
\hline \multirow[t]{2}{*}{ Experiment } & \multicolumn{3}{|l|}{$\mathrm{B}_{\mathrm{i}}\left({ }^{\circ}\right.$ Brix $)$} & \multirow{2}{*}{$\frac{\mathrm{T}\left({ }^{\circ} \mathrm{C}\right)}{\text { All fruits }}$} & \multirow{2}{*}{$\frac{C_{\text {inoc }}\left(\mathrm{g} \cdot \mathrm{L}^{-1}\right)}{\text { All fruits }}$} \\
\hline & Mango & $\begin{array}{l}\text { Cherry and } \\
\text { orange }\end{array}$ & Banana & & \\
\hline 1 & $-1(14.0)$ & $-1(14.5)$ & $-1(14.3)$ & $-1(18.0)$ & $0(0.6)$ \\
\hline 2 & $1(24.0)$ & $1(24.0)$ & $1(24.3)$ & $-1(18.0)$ & $0(0.6)$ \\
\hline 3 & $-1(14.0)$ & $-1(14.5)$ & $-1(14.3)$ & $1(32.0)$ & $0(0.6)$ \\
\hline 4 & $1(24.0)$ & $1(24.0)$ & $1(24.3)$ & $1(32.0)$ & $0(0.6)$ \\
\hline 5 & $-1(14.0)$ & $-1(14.5)$ & $-1(14.3)$ & $0(25.0)$ & $-1(0.3)$ \\
\hline 6 & $1(24.0)$ & $1(24.0)$ & $1(24.3)$ & $0(25.0)$ & $-1(0.3)$ \\
\hline 7 & $-1(14.0)$ & $-1(14.5)$ & $-1(14.3)$ & $0(25.0)$ & $1(0.9)$ \\
\hline 8 & $1(24.0)$ & $1(24.0)$ & $1(24.3)$ & $0(25.0)$ & $1(0.9)$ \\
\hline 9 & $0(19.0)$ & $0(19.5)$ & $0(19.3)$ & $-1(18.0)$ & $-1(0.3)$ \\
\hline 10 & $0(19.0)$ & $0(19.5)$ & $0(19.3)$ & $1(32.0)$ & $-1(0.3)$ \\
\hline 11 & $0(19.0)$ & $0(19.5)$ & $0(19.3)$ & $-1(18.0)$ & $1(0.9)$ \\
\hline 12 & $0(19.0)$ & 0 (19.5) & $0(19.3)$ & $1(32.0)$ & $1(0.9)$ \\
\hline 13 & $0(19.0)$ & $0(19.5)$ & $0(19.3)$ & $0(25.0)$ & $0(0.6)$ \\
\hline 14 & $0(19.0)$ & $0(19.5)$ & $0(19.3)$ & $0(25.0)$ & $0(0.6)$ \\
\hline 15 & $0(19.0)$ & $0(19.5)$ & $0(19.3)$ & $0(25.0)$ & $0(0.6)$ \\
\hline
\end{tabular}

measured using a Jasco RI-1530 detector. Proper standards were used for quantification.

\subsubsection{Major volatile compounds}

Major volatiles were analyzed after adding $410 \mu \mathrm{g}$ of 4-nonanol (internal standard) to $5 \mathrm{~mL}$ of sample. A Chrompack CP-9000 gas chromatograph equipped with a split/splitless injector, a flame ionization detector (FID) and a capillary column, coated with CP-Wax $57 \mathrm{CB}(50 \mathrm{~m} \times 0.25 \mathrm{~mm} ; 0.2 \mu \mathrm{m}$ film thickness, Chrompack), was used. Injector and detector temperatures were set to $250{ }^{\circ} \mathrm{C}$. Oven temperature was initially held at $60^{\circ} \mathrm{C}$, for $5 \mathrm{~min}$, then programmed to rise from $60^{\circ} \mathrm{C}$ to $220^{\circ} \mathrm{C}$, at $3^{\circ} \mathrm{C} \mathrm{min}-1$, and maintained at $220^{\circ} \mathrm{C}$ for $10 \mathrm{~min}$. The carrier gas was helium $4 \times$ (Praxair) at an initial flow rate of $1 \mathrm{~mL} \mathrm{~min}^{-1}$ (125 kPa at the head of the column). Analyses were performed by injecting $1 \mu \mathrm{L}$ of sample in the split mode $\left(15 \mathrm{~mL} \mathrm{~min}^{-1}\right)$. Quantification of major volatiles was performed using Star-Chromatography Workstation version 6.41 (Varian) software, taking into account the detector response factor for each analyte and comparing retention times with those of pure standards.

\subsubsection{Minor volatile compounds}

Minor volatiles were analyzed by GC-MS after extraction of $8 \mathrm{~mL}$ of sample with $400 \mu \mathrm{L}$ of dichloromethane, spiked with $3.28 \mu \mathrm{g}$ of 4nonanol (IS). A gas chromatograph Varian 3800 with a 1079 injector and an ion-trap mass spectrometer Varian Saturn 2000 was used. $1 \mu \mathrm{L}$ injections were made in splitless mode (30 s) in a Varian Factor Four VF-Wax ms column ( $30 \mathrm{~m} \times 0.15 \mathrm{~mm}$; $0.15 \mu \mathrm{m}$ film thickness). Carrier gas was helium $4 \times$ (Praxair) at a constant flow of $1.3 \mathrm{~mL} \cdot \mathrm{min}^{-1}$. The detector was set to electronic impact mode with an ionization energy of $70 \mathrm{eV}$, mass acquisition range from $35 \mathrm{~m} / z$ to $260 \mathrm{~m} / \mathrm{z}$ and acquisition interval of $610 \mathrm{~ms}$. Oven temperature was initially set to $60^{\circ} \mathrm{C}$ for $2 \mathrm{~min}$ and then raised from $60^{\circ} \mathrm{C}$ to $234^{\circ} \mathrm{C}$ at $3{ }^{\circ} \mathrm{C} \mathrm{min}^{-1}$, raised from $234{ }^{\circ} \mathrm{C}$ to $250{ }^{\circ} \mathrm{C}$ at $10{ }^{\circ} \mathrm{C} \mathrm{min}{ }^{-1}$ and maintained at $250^{\circ} \mathrm{C}$ for $10 \mathrm{~min}$. Injector temperature was maintained at $250^{\circ} \mathrm{C}$ during analysis and the split flow was maintained at

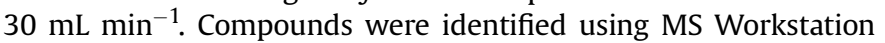
version 6.9 (Varian) software, by comparing their mass spectra and retention indexes with those of pure standards. Minor compounds were quantified in terms of 4-nonanol equivalents.

\subsubsection{Antioxidant activity}

Antioxidant activity was evaluated using Ferric Reducing Antioxidant Power (FRAP) assay. $10 \mu \mathrm{L}$ of sample were mixed, in a 96 well microplate, with $290 \mu \mathrm{L}$ of freshly prepared FRAP reagent. FRAP reagent was prepared by mixing a $10 \mathrm{mmol} \cdot \mathrm{L}^{-1}$ 2,4,6-tris-(1pyridyl)-5-triazine (TPTZ) solution (made with $40 \mathrm{mmol} \cdot \mathrm{L}^{-1} \mathrm{HCl}$ ) with a $20 \mathrm{mmol} \cdot \mathrm{L}^{-1} \mathrm{FeCl}_{3}$ solution and $300 \mathrm{mmol} \cdot \mathrm{L}^{-1}$ acetate buffer (pH 3.6) in a volumetric proportion of $1: 1: 10$. After mixing, samples were incubated at $37{ }^{\circ} \mathrm{C}$ followed by determination of the absorbance at $593 \mathrm{~nm}$. FRAP activity was expressed as concentration of $\mathrm{Fe}_{2} \mathrm{SO}_{4}$ equivalents, supported by the proper calibration curve.

\subsection{Sensory analysis of fruit wines}

\subsubsection{Sensory evaluation}

Sensory analysis was carried out by seven trained panellists from Rias Baixas A.O.C. (Galicia, Spain), two male and five female, ages between 40 and 50 years. All judges were experienced tasters and have previously participated in similar studies. Judging was performed in a professional-standard room in agreement with the ISO Norm 8589 (1988). Evaluation was carried out in two sessions. In the first, evaluation was carried out using the QDA methodology, to establish fruit wines descriptors. One training period of $1 \mathrm{~h}$ was carried out, where judges generated visual, olfactory and gustatory descriptive terms to define the fermented fruit samples. In the second session, a sample volume of $30 \mathrm{~mL}$ of was evaluated in taster glasses at $12{ }^{\circ} \mathrm{C}$. During the analysis, judges scored the intensity of each attribute using a 9-point scale, where 9 indicated a very high intensity. The relative frequency $(F)$, relative intensity $(I)$ and geometric mean $(G M)$ of the different descriptors were calculated for each sample. Geometric mean was calculated as the square root of the product between relative intensity and relative frequency.

$\mathrm{GM} /(\%)=\sqrt{I \times F} \times 100$

I corresponds to the sum of the intensities given by the panel for a descriptor, divided by the maximum possible intensity for this descriptor; and $F$ is the number of times that the descriptor was mentioned divided by the maximum number of times that it could be mentioned.

Descriptors were classified for each sample using the GM according to the International Organization for Standardization - ISO Norm 11035 (1994), which allowed the elimination of the descriptors whose geometric means were relatively low. This method allowed taking into account descriptors rarely mentioned but very important in terms of perceived intensity, and descriptors with a low perceived intensity but often mentioned.

\subsubsection{Data analysis}

Sensory and instrumental data were analyzed using XLstat-Pro. Relative intensity $(I)$ and Geometric mean (GM) data were statistically analyzed using multivariate techniques. To show the relationship between sensory variables and volatile families, Partial Least Squares Regression (PLSR2) was applied. PLSR2 shows the relationship between $X$ data (volatile compounds) and $Y$ data (sensory descriptor). The $X$ data are actively used in estimating the latent variables to ensure that the first components are those that are most relevant for predicting the $Y$ variable. This is a data reduction technique since it reduces the $X$ variables to a set of no correlated factors that describe the variation in the data.

\section{Results and discussion}

\subsection{Fruit wine production optimization}

Fermentations were conducted in order to evaluate ethanol production and productivity as described in 2.4 . The resulting data (supplied in Supplementary Table 1) allowed mathematical modeling of fermentation response for each fruit, with the resulting 
Table 3

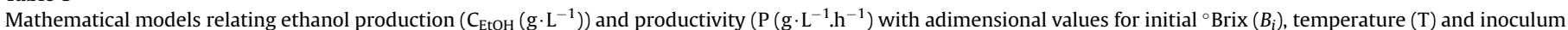
concentration $\left(C_{\text {inoc }}\right)$ for each fruit, resulting from the factorial design. $\mathrm{R}^{2}$ is the regression coefficient of the model.

\begin{tabular}{|c|c|c|}
\hline Fruit & Model for ethanol yield & $\mathrm{R}^{2}$ \\
\hline Orange & $\begin{array}{l}C_{E t O H}=60.2886+11.5188 * \mathrm{Bi}-2.2024 * T+0.1842 * C_{\text {inoc }}+0.0088 * \mathrm{~B}_{\mathrm{i}}^{2}+7.6978 * \mathrm{~B}_{\mathrm{i}} * T+3.9246 * \mathrm{~B}_{\mathrm{i}} * \mathrm{C}_{\text {inoc }}-8.6496 * T^{2}-1.7994 * T * \mathrm{C}_{\text {inoc }}-3.3039 * \mathrm{C}_{\text {inoc }}{ }^{2} \\
P=0.4286+0.0311 * \mathrm{~B}_{\mathrm{i}}+0.1476 * T+0.0146 * \mathrm{C}_{\text {inoc }}+0.0104 * \mathrm{~B}_{\mathrm{i}}^{2}+0.0741 * \mathrm{~B}_{\mathrm{i}} * T+0.0138 * \mathrm{~B}_{\mathrm{i}} * \mathrm{C}_{\text {inoc }}-0.0952 * T^{2}+0.0025 * T * \mathrm{C}_{\text {inoc }}-0.0427 * \mathrm{C}_{\text {inoc }}{ }^{2}\end{array}$ & 0.921 \\
\hline Mango & $\begin{array}{l}C_{E t O H}=71.0173+19.4419 * B_{i}+2.8077 * T+1.2978 * C_{\text {inoc }}+3.4986 * \mathrm{~B}_{\mathrm{i}}^{2}-2.6515 * \mathrm{~B}_{\mathrm{i}} * T+2.2436 * \mathrm{~B}_{\mathrm{i}} * \mathrm{C}_{\text {inoc }}-2.6432 * T^{2}-4.3720 * T * \mathrm{C}_{\text {inoc }}-3.8604 * \mathrm{C}_{\text {inoc }}{ }^{2} \\
P=1.2244+0.0545 * \mathrm{~B}_{\mathrm{i}}+0.3987 * T-0.0169 * \mathrm{C}_{\text {inoc }}-0.2197 * \mathrm{~B}_{\mathrm{i}}{ }^{2}+0.0292 * \mathrm{~B}_{\mathrm{i}} * T+0.1023 * \mathrm{~B}_{\mathrm{i}} * \mathrm{C}_{\text {inoc }}-0.2000 * T^{2}-0.0629 * T * \mathrm{C}_{\text {inoc }}-0.0788 * \mathrm{C}_{\text {inoc }}{ }^{2}\end{array}$ & 0.924 \\
\hline Cherry & $\begin{array}{l}C_{E t O H}=52.2794+15.3397 * \mathrm{~B}_{\mathrm{i}}-0.1941 * T-0.6810 * \mathrm{C}_{\text {inoc }}+0.1316 * \mathrm{~B}_{\mathrm{i}}^{2}+0.0329 * \mathrm{~B}_{\mathrm{i}} * T-0.5329 * \mathrm{~B}_{\mathrm{i}} * \mathrm{C}_{\text {inoc }}+0.4803 * T^{2}+0.3224 * T * \mathrm{C}_{\text {inoc }}+1.5593 * \mathrm{C}_{\text {inoc }}{ }^{2} \\
P=1.8671+0.1133 * \mathrm{~B}_{\mathrm{i}}+0.8186 * T+0.1646 * \mathrm{C}_{\text {inoc }}-0.1358 * \mathrm{~B}_{\mathrm{i}}^{2}+0.0103 * \mathrm{~B}_{\mathrm{i}} * T+0.0015 * \mathrm{~B}_{\mathrm{i}} * \mathrm{C}_{\text {inoc }}-0.1128 * T^{2}+0.0334 * T * \mathrm{C}_{\text {inoc }}+0.0245 * C_{\text {inoc }}\end{array}$ & $\begin{array}{l}0.999 \\
0.990\end{array}$ \\
\hline Banana & $\begin{array}{l}C_{E t O H}=82.6233+13.7804 * B_{i}+1.7896 * T+0.0526 * C_{\text {inoc }}-8.3952 * B_{i}^{2}+2.1778 * B_{i} * T-0.3553 * B_{i} * C_{\text {inoc }}+2.7896 * T^{2}+0.7632 * T * C_{\text {inoc }}-4.8687 * C_{\text {inoc }}{ }^{2} \\
P=1.2805-0.2935 * B_{i}+0.3836 * T+0.1402 * C_{\text {inoc }}-0.2386 * B_{i}^{2}-0.1109 * B_{i} * T-0.0586 * B_{i} * C_{\text {inoc }}-0.0424 * T^{2}+0.0022 * T * C_{\text {inoc }}-0.0877 * C_{\text {inoc }}{ }^{2}\end{array}$ & $\begin{array}{l}0.933 \\
0.940\end{array}$ \\
\hline
\end{tabular}

models presented in Table 3. Mathematical models showed proper adjustment to the experimental data, demonstrated by the $R^{2}$ values obtained in the range of $0.9-1$. Optimal ethanol and productivity values were predicted for each fruit and are presented in Table 4. Optimal conditions determined were within the values studied in the assays. Optimal $B_{i}$ was consistent with maximal ethanol production, close to the highest $B_{i}$ studied in the experimental designs and inherent to high sugar content in the must. Similar optimal fermentation temperatures for all fruits were obtained, between $22.6^{\circ} \mathrm{C}$ and $24.7^{\circ} \mathrm{C}$, with the exception of banana with optimal fermentation temperature of $31.9{ }^{\circ} \mathrm{C}$. This process parameter is highly influenced by the yeast used, which for the microorganism in use is in the range of $14.0^{\circ} \mathrm{C}-28.0^{\circ} \mathrm{C}$, as indicated by the supplier. However, optimal process temperature can be influenced by the rheological properties of the must, and in the case of banana must, its high viscosity can affect yeast growth and $\mathrm{CO}_{2}$ diffusion, leading to a deviation in the optimal temperature value. Inoculum concentration values ranged through the entire interval studied, implying a strong influence of the fruit used on the amount of inoculum needed. Overall, response factors predicted were coherent with the expected from the conditions established. To confirm the relations established by the models, a validation assay was conducted in conditions similar to the optimal predicted, adjusting only fermentation temperature to $23.5^{\circ} \mathrm{C}$ for orange, mango and cherry fermentations. Fermentations were monitored by $\mathrm{CO}_{2}$ mass loss to determine fermentation time and calculate productivity, with fermentation profiles presented in Fig. 1. Banana, cherry and mango fermentations presented reduced lag phases, whereas orange presented a longer lag phase which can be related to yeast inhibition by orange must composition. Banana and mango fermentations entered stationary phase at about $100 \mathrm{~h}$ of fermentation, cherry at $40 \mathrm{~h}$ and orange at $190 \mathrm{~h}$. The relative $\mathrm{CO}_{2}$

Table 4

Optimal process conditions (Initial Brix $\left(B_{i}\right)$, Temperature $(T)$ and Inoculum concentration $\left(\mathrm{C}_{\text {inoc }}\right)$ ) and correspondent responses $\left(\mathrm{C}_{\mathrm{EtOH}}\right)$ and Productivity $(\mathrm{P})$, predicted values using mathematical models for maximal ethanol production and for the validation conditions and experimental values obtained in the validation assay (real values). Errors represent standard deviations from fermentation triplicates and standard error for the estimate.

\begin{tabular}{|c|c|c|c|c|c|}
\hline \multirow[t]{2}{*}{ Fruit } & \multicolumn{3}{|c|}{ Optimal conditions } & \multicolumn{2}{|l|}{ Optimal responses } \\
\hline & $\mathrm{B}_{\mathrm{i}} /{ }^{\circ} \mathrm{B}$ & $\mathrm{T} /{ }^{\circ} \mathrm{C}$ & $\mathrm{C}_{\text {inoc }} / \mathrm{g} \cdot \mathrm{L}^{-1}$ & $\mathrm{C}_{\mathrm{EtOH}} / \mathrm{g} \cdot \mathrm{L}^{-1}$ & $\mathrm{P} / \mathrm{g} \cdot \mathrm{L}^{-1} \cdot \mathrm{h}^{-1}$ \\
\hline Cherry & 22.9 & 22.6 & 0.49 & $63.4 \pm 0.63$ & $1.5 \pm 0.1$ \\
\hline Orange & 24.2 & 24.7 & 0.72 & $72.0 \pm 5.44$ & $0.5 \pm 0.0$ \\
\hline Mango & 24.0 & 23.2 & 0.83 & $94.9 \pm 7.46$ & $1.0 \pm 0.2$ \\
\hline \multirow[t]{3}{*}{ Banana } & 24.2 & 31.9 & 0.63 & $94.7 \pm 5.29$ & $1.0 \pm 0.2$ \\
\hline & \multicolumn{3}{|c|}{ Validation conditions } & \multicolumn{2}{|c|}{ Predicted values/Real values } \\
\hline & $\mathrm{B}_{\mathrm{i}} /{ }^{\circ} \mathrm{B}$ & $\mathrm{T} /{ }^{\circ} \mathrm{C}$ & $\mathrm{C}_{\text {inoc }} / \mathrm{g} \cdot \mathrm{L}^{-1}$ & $\mathrm{C}_{\mathrm{EtOH}} / \mathrm{g} \cdot \mathrm{L}^{-1}$ & $\mathrm{P} / \mathrm{g} \cdot \mathrm{L}^{-1} \cdot \mathrm{h}^{-1}$ \\
\hline Cherry & 22.9 & 23.5 & 0.49 & $63.0 \pm 0.7 / 66 \pm 4$ & $1.6 \pm 0.1 / 1.7 \pm 0.2$ \\
\hline Orange & 24.2 & 23.5 & 0.72 & $71 \pm 5 / 72 \pm 2$ & $0.4 \pm 0.0 / 0.4 \pm 0.0$ \\
\hline Mango & 24.0 & 23.5 & 0.83 & $95 \pm 7 / 101 \pm 1.8$ & $1.0 \pm 0.2 / 1.0 \pm 0.1$ \\
\hline Banana & 24.2 & 31.9 & 0.63 & $95 \pm 5 / 98 \pm 8$ & $1.0 \pm 0.2 / 1.0 \pm 0.1$ \\
\hline
\end{tabular}

production for all of them was consistent with the expected ethanol yield. Ethanol yield and productivity values obtained are presented in Table 4, alongside with the values predicted by the models for the validation assay conditions.

Ethanol yield and productivity in the validation assay were in good agreement with the responses predicted using the models, reinforcing their validity. Despite similar $B_{i}$ for all four fermentations, cherry and orange presented lower ethanol productions than the ones observed for mango and banana. To substantiate these yields, fermentable sugar concentration was measured in each must and is presented in Table 5.

Fermentable sugars concentration in cherry must was lower in comparison with the other fruit, justifying the lower ethanol yield. In orange fermentation the lower ethanol yield can be a direct consequence of the long lag phase observed, probably caused by the presence of inhibitors in the concentrated must. This long lag phase influenced also productivity of orange wine, being largely inferior in comparison with the other fermentations. Nevertheless, orange fermentation allowed the production of a wine with $72.3 \pm 2.08 \mathrm{~g} \cdot \mathrm{L}^{-1}$ of ethanol, without sugar addition to the must, 0.2 folds superior to the reported (Santos et al., 2013). Mango and banana presented similar fermentation behaviors, in good agreement with the chemical similarities of both musts allowing ethanol yields 1.5 and 0.5 folds superior to ones previously reported (Akubor, Obio, Nwadomere, \& Obiomah, 2003; Reddy \& Reddy, 2009).

Considering the results, optimization was successfully attained, with the mathematical models in good agreement with the experimental data. Ethanol yield and productivity were maximized in the studied conditions, making the process feasible for industrial implementation. Furthermore, mathematical models described are of upmost importance for selecting process conditions and predicting responses if alternative applications, quality features or subsequent processing steps are desired. Due to the use of fruit

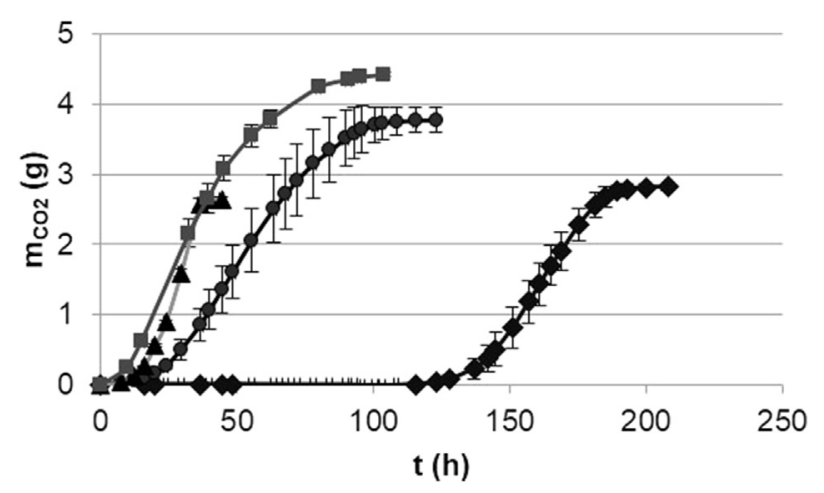

Fig. 1. $\mathrm{CO}_{2}$ production and exhaustion $\left(\mathrm{m}_{\mathrm{CO} 2}\right)$ during time-course $(\mathrm{t})$ of alcoholic fermentation using optimal conditions predicted by ethanol production models for $(-)$ Orange, $(-\bullet)$ Mango, $(\bullet-)$ Cherry and $(--)$ Banana. 
Table 5

HPLC analysis of sugar content in fruit musts (sum of fermentable sugars concentrations) and main organic acids found in fruit wines. Errors represent standard deviation from fermentation triplicates.

\begin{tabular}{lllll}
\hline \multirow{2}{*}{ Fruit } & Fruit musts & & Fruit wines \\
\cline { 2 - 3 } & Fermentable sugars $\left(\mathrm{g} \cdot \mathrm{L}^{-1}\right)$ & & Citric acid $\left(\mathrm{g} \cdot \mathrm{L}^{-1}\right)$ & Malic acid $\left(\mathrm{g} \cdot \mathrm{L}^{-1}\right)$ \\
\hline Orange & $193 \pm 1.43$ & $41.2 \pm 0.57$ & $0.00 \pm 0.00$ \\
Mango & $182 \pm 1.30$ & $9.15 \pm 0.87$ & $0.87 \pm 0.21$ \\
Cherry & $127 \pm 1.00$ & $5.01 \pm 0.25$ & $37.0 \pm 1.46$ \\
Banana & $181 \pm 1.30$ & $4.27 \pm 0.15$ & $4.78 \pm 0.10$ \\
\hline
\end{tabular}

concentrates, ethanol yields in all fruit wines were superior to the observed in previous works, without the need for sugar addition or other strategies. Ethanol yield was within the ranges observed in grape wines, demonstrating the feasibility of fruit wine production from concentrates.

\subsection{Characterization of fruit wines}

Considering the production of a fermented beverage, with organoleptic and functional value, a characterization of the key compounds was conducted, in order to evaluate fruit wine composition.

\subsubsection{Organic acid composition}

Among the compounds participating in wine flavor, organic acids may be considered as one of the main contributors to taste. Citric and malic acids are present in most fruit species (Tucker, 1993) and therefore dominant in fruit wines. Organic acids composition of the produced fruit wines is presented in Table 5. Citric acid was mainly found in orange and present in lower concentration in mango, cherry and banana wines. Malic acid was mainly found in cherry, with much lower concentration in banana, residual in mango and null in orange. Organic acids in fruit wines were highly fruit dependent, which is in good agreement with the described for the corresponding fruit, namely high content of citric acid in orange (Kelebek, Selli, Canbas, \& Cabaroglu, 2009) and malic acid in cherry fruit (Usenik, Fabcic, \& Stampar, 2007). In comparison to cherry and orange, mango and banana wines showed lower concentrations of these organic acids, also coherent with the titrable acidity previously reported for these wines (Akubor et al., 2003; Reddy \& Reddy, 2009). The use of fruit concentrates in this work led to higher concentrations of these organic acids, when compared to the naturally found in the fruit, potentiating acidic flavors in the corresponding wines.

\subsubsection{Antioxidant activity (FRAP)}

Antioxidant activity of fruit wines and musts was evaluated in order to assess the impact of alcoholic fermentation on this feature and the functional potential of fruit wines. For this purpose an FRAP analysis was performed with results presented in Table 6. Fruit

\section{Table 6}

Antioxidant activities in fruit musts and fruit wines produced from concentrates, in comparison with the ones previously reported for the corresponding fruits. Errors represent standard deviations of fermentation triplicates* adapted from (Fu et al., 2011).

\begin{tabular}{llll}
\hline $\begin{array}{l}\text { Antioxidant } \\
\text { activity }\end{array}$ & $\begin{array}{l}\text { Fruit must } \\
\left(\mathrm{mmol} \cdot \mathrm{L}^{-1}\right)\end{array}$ & $\begin{array}{l}\text { Fruit wine } \\
\left(\mathrm{mmol} \cdot \mathrm{L}^{-1}\right)\end{array}$ & $\begin{array}{l}\text { Fruit } \\
\left(\mathrm{mmol} \cdot \mathrm{kg}^{-1}\right)^{*}\end{array}$ \\
\hline Orange & $24.8 \pm 0.01$ & $22.6 \pm 0.46$ & $13.4 \pm 0.26$ \\
Cherry & $33.6 \pm 0.02$ & $28.0 \pm 1.84$ & $14.6 \pm 0.33$ \\
Mango & $5.38 \pm 0.00$ & $7.14 \pm 0.77$ & $4.86 \pm 0.19$ \\
Banana & $10.3 \pm 0.00$ & $9.54 \pm 0.89$ & $5.33 \pm 0.10$ \\
\hline
\end{tabular}

demonstrated distinctive antioxidant activities, where orange and cherry presented the highest antioxidant activity among the ones tested. High concentrations of phenolic compounds and anthocyanins have been reported for cherry, both responsible for its antioxidant activity (Usenik et al., 2007). Orange is known to contain carotenoids, vitamin $\mathrm{C}$ and phenolic compounds (Kelebek et al., 2009), also broadly acknowledged by their high antioxidant activity. Comparing all four fruit, relative antioxidant activities are in accordance with the previously reported (Fu et al., 2011) as shown in Table 6, where banana and mango wines demonstrated lower antioxidant activity than orange and cherry wines, measured by FRAP. Antioxidant activity was highly fruit dependent and the impact of alcoholic fermentation on this feature was low. Furthermore, the utilization of fruit concentrates allowed the production of wines with around 50\%-90\% higher antioxidant activity than the ones naturally found in the corresponding fruit (Fu et al., 2011) as shown in Table 6, adding further potential to these wines for functional food-grade formulations. Despite not posing as functional foods themselves, fruit wines can be further processed and included in novel formulations, representing an attractive alternative for preservation and delivery of fruit nutritional properties.

\subsection{Fruit wines aromatic and sensory characterization}

\subsubsection{Major volatile compounds}

Fruit wines were analyzed by GC-FID, in order to quantify major volatiles. Twelve compounds were quantified, with the concentrations presented in Table 7. Alcohols and esters were the main major volatiles found. Despite having low contribution to wine aroma, these compounds contribute to secondary aroma and enhance sensory perception of primary odors (Ribéreau-Gayon et al., 2006). One important compound is methanol, due to its toxic nature at high concentrations, and it was found in all fruit wines. The appearance of this alcohol in wine is related to pectin content in the must (Ribéreau-Gayon et al., 2006), and dependent of the fruit and fractions used, justifying the differences observed. Nevertheless, methanol was below the maximum level of $250 \mathrm{mg} \cdot \mathrm{L}^{-1}$ established by wine regulation (OIV, 2014) in all fruit wines. Also found in high concentrations were 1-propanol, 3methyl-1-butanol and 2,3-butanediol, products of yeast metabolism, deriving from the anabolic glucose pathway or specific amino acid catabolic pathway (Ribéreau-Gayon et al., 2006). Considering that these secondary metabolites are a direct consequence of the fermentation of specific substrates in the raw material, the concentrations observed can be influenced by the distinct composition of each fruit concentrate. Other compounds considered to have low impact on wine quality (Ribéreau-Gayon et al.,

Table 7

Quantification of major compounds in fruit wines by GC-FID, errors represent standard deviation of fermentation triplicates.

\begin{tabular}{|c|c|c|c|c|}
\hline & Orange & Mango & Cherry & Banana \\
\hline & $\mathrm{C}\left(\mathrm{mg} \cdot \mathrm{L}^{-1}\right)$ & $\mathrm{C}\left(\mathrm{mg} \cdot \mathrm{L}^{-1}\right)$ & $\mathrm{C}\left(\mathrm{mg} \cdot \mathrm{L}^{-1}\right)$ & $\mathrm{C}\left(\mathrm{mg} \cdot \mathrm{L}^{-1}\right)$ \\
\hline acetaldehyde & $13 \pm 1.4$ & $21 \pm 3$ & $7 \pm 1.2$ & $5.3 \pm 0.7$ \\
\hline methyl acetate & $7 \pm 1.1$ & $6.9 \pm 1.4$ & $0.0 \pm 0.0$ & $3.4 \pm 0.3$ \\
\hline ethyl acetate & $13.3 \pm 0.5$ & $40 \pm 3$ & $18 \pm 1.0$ & $66 \pm 38$ \\
\hline methanol & $213 \pm 40$ & $109 \pm 31$ & $17 \pm 6$ & $42 \pm 12$ \\
\hline 1-propanol & $116 \pm 4$ & $87 \pm 9$ & $236 \pm 29$ & $193 \pm 50$ \\
\hline 2-methyl-1-propanol & $15 \pm 1.4$ & $45 \pm 1.3$ & $25 \pm 1.7$ & $64 \pm 19$ \\
\hline 2-methyl-1-butanol & $18.7 \pm 0.8$ & $43 \pm 2$ & $15 \pm 1.6$ & $25 \pm 7$ \\
\hline 3-methyl-1-butanol & $70 \pm 1.3$ & $164 \pm 12$ & $120 \pm 1.2$ & $100 \pm 26$ \\
\hline 2,3-butanediol, levo & $208 \pm 26$ & $245 \pm 82$ & $305 \pm 63$ & $365 \pm 80$ \\
\hline 2,3-butanediol, meso & $65 \pm 12$ & $93 \pm 32$ & $88 \pm 21$ & $119 \pm 27$ \\
\hline diethyl succinate & $0.0 \pm 0.0$ & $0.0 \pm 0.0$ & $0.0 \pm 0.0$ & $1.4 \pm 0.4$ \\
\hline 2-phenylethanol & $12 \pm 2$ & $46 \pm 11$ & $8 \pm 1.8$ & $8 \pm 2$ \\
\hline
\end{tabular}


Table 8

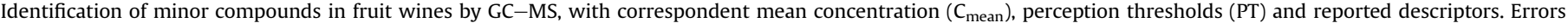
represent standard deviation of fermentation triplicates.

\begin{tabular}{|c|c|c|c|c|c|c|}
\hline & \multirow{2}{*}{$\frac{\text { Banana }}{C_{\text {mean }}\left(\mu \mathrm{g} \cdot \mathrm{L}^{-1}\right)}$} & \multirow{2}{*}{$\frac{\text { Cherry }}{C_{\text {mean }}\left(\mu \mathrm{g} \cdot \mathrm{L}^{-1}\right)}$} & \multirow{2}{*}{$\frac{\text { Mango }}{C_{\text {mean }}\left(\mu \mathrm{g} \cdot \mathrm{L}^{-1}\right)}$} & \multirow{2}{*}{$\frac{\text { Orange }}{C_{\text {mean }}\left(\mu \mathrm{g} \cdot \mathrm{L}^{-1}\right)}$} & \multirow{2}{*}{$\frac{\text { Threshold }}{P T\left(\mu \mathrm{g} \cdot \mathrm{L}^{-1}\right)}$} & \multirow[t]{2}{*}{ Descriptors } \\
\hline & & & & & & \\
\hline \multicolumn{7}{|l|}{$\mathrm{C}_{6}$-Compounds } \\
\hline 1-hexanol & $159 \pm 59$ & $10 \pm 1$ & - & $192 \pm 62$ & $8000[1][2]^{\mathrm{b}}$ & \\
\hline Z-3-hexenol & - & - & - & $96 \pm 28$ & $400[1]^{\mathrm{b}}$ & Lettuce-like [3] \\
\hline \multicolumn{7}{|l|}{ Alcohols } \\
\hline 3-ethoxy-1-propanol & $404 \pm 146$ & $68 \pm 5$ & $294 \pm 75$ & $218 \pm 57$ & $50000[2]^{\mathrm{b}}$ & - \\
\hline 1-octanol & - & - & - & $1053 \pm 118$ & $10000[2]^{\mathrm{b}}$ & Coconut,nuts,oily [4] \\
\hline Furfuryl alcohol & - & - & $161 \pm 44$ & - & $15000[5]^{\mathrm{a}}$ & Hay,Moldy [5] \\
\hline benzyl alcohol & - & $382 \pm 32$ & $17 \pm 4$ & $56 \pm 17$ & $200000[6]^{\mathrm{a}}$ & Almonds,Bitter [4] \\
\hline 2-phenoxyethanol & - & $9 \pm 1$ & - & - & - & - \\
\hline \multicolumn{7}{|l|}{ Esters } \\
\hline isobutyl acetate & - & $59 \pm 1$ & $342 \pm 46$ & - & $1605[7]^{\mathrm{a}}$ & Banana,fruity,sweet [4] \\
\hline ethyl butyrate & - & $52 \pm 10$ & $365 \pm 115$ & $121 \pm 0.6$ & $20[1][2]^{\mathrm{b}}$ & Fruity [3], Papaia,Sweet,Butter,Apple [4] \\
\hline 3-methylbutyl acetate & $3762 \pm 1460$ & $1034 \pm 16$ & $2674 \pm 879$ & $293 \pm 62$ & $30[1][2]^{\mathrm{b}}$ & Banana,apple,solvent [4] \\
\hline ethyl hexanoate & $912 \pm 400$ & $122 \pm 8$ & $414 \pm 99$ & $154 \pm 46$ & $14[8]^{\mathrm{a}}$ & Apple,Fruity,Aniseed,Sweet [4] \\
\hline Z-3-hexenyl acetate & - & $15 \pm 0.3$ & - & - & - & - \\
\hline ethyl octanoate & $466 \pm 160$ & $43 \pm 7$ & $95 \pm 13$ & $127 \pm 36$ & $5[8]^{\mathrm{a}}$ & Apple,Sweet,Fruity [4] \\
\hline ethyl 3-hydroxybutyrate & $45 \pm 15$ & $4 \pm 1$ & $319 \pm 50$ & $9 \pm 0$ & $20000[6]^{\mathrm{a}}$ & - \\
\hline ethyl decanoate & $273 \pm 134$ & $17 \pm 2$ & $29 \pm 14$ & $39 \pm 11$ & $200[8]^{\mathrm{a}}$ & Fatty acid,fruity,apple,solvent [4] \\
\hline benzyl acetate & - & $36 \pm 3$ & - & - & - & - \\
\hline 2-phenylethyl acetate & $659 \pm 204$ & $98 \pm 9$ & - & $296 \pm 81$ & $650[9] 250[1][2]^{\mathrm{b}}$ & Roses,honey,apple,sweet [4] \\
\hline \multicolumn{7}{|l|}{ Monoterpenic alcohols } \\
\hline linalool & - & $39 \pm 6$ & $44 \pm 16$ & $6725 \pm 1561$ & $25.2[8]^{\mathrm{a}}$ & Aniseed,terpene [4] Lemon [10] \\
\hline isopulegol I & - & - & - & $184 \pm 40$ & - & - \\
\hline fenchol & - & - & $42 \pm 6$ & - & $50[11]^{\mathrm{C}}$ & muddy [12] \\
\hline terpinen-4-ol & - & $14 \pm 6$ & $91 \pm 21$ & $12404 \pm 3146$ & - & - \\
\hline myrcenol & - & - & $35 \pm 3$ & - & - & - \\
\hline borneol & - & - & $54 \pm 15$ & - & - & - \\
\hline$\alpha$-terpineol & - & $12 \pm 4$ & $1036 \pm 275$ & $3683 \pm 984$ & $250[8]^{\mathrm{a}}$ & Pine,terpene [4] \\
\hline citronellol & - & $9 \pm 2$ & - & $307 \pm 81$ & $100[1][2]^{\mathrm{b}}$ & Citronella [13] \\
\hline nerol & - & $8 \pm 2$ & - & $280 \pm 32$ & $400-500[14]^{c}$ & Lime,floral-hyacinth,roses [4] \\
\hline geraniol & - & $14 \pm 1$ & - & $241 \pm 64$ & $36[10]^{\mathrm{a}}$ & rose-like,citrus-like [3] \\
\hline \multicolumn{7}{|l|}{ Monoterpenic oxides and diols } \\
\hline trans-furan linalool oxide & - & - & $93 \pm 11$ & - & - & - \\
\hline cis-furan linalool oxide & - & - & $70 \pm 22$ & $93 \pm 20$ & - & - \\
\hline 8-hydroxy-6,7-dihydrolinalool & - & - & - & $168 \pm 55$ & - & - \\
\hline E-8-hidrohylinalool & - & $11 \pm 1$ & - & $261 \pm 99$ & - & - \\
\hline Z-8-hidrohylinalool & - & $14 \pm 2$ & - & $132 \pm 31$ & - & - \\
\hline C13-Norisoprenoids & & & & & & \\
\hline 3-hydroxy- $\beta$-damascone & - & $51 \pm 4$ & - & - & - & - \\
\hline 3-hydroxy-7,8-dihydro- $\alpha$-ionone & - & $12 \pm 2$ & - & - & - & - \\
\hline 3-oxo- $\alpha$-ionol & $30 \pm 17$ & $665 \pm 76$ & $41 \pm 12$ & $507 \pm 156$ & - & - \\
\hline 3-oxo-7,8-dihydro- $\alpha$-ionol & $63 \pm 36$ & $45 \pm 6$ & $155 \pm 40$ & $281 \pm 84$ & - & - \\
\hline Volatile phenols & & & & & & \\
\hline eugenol & $8205 \pm 3027$ & $225 \pm 39$ & - & $236 \pm 76$ & $6[8] ; 15[5]^{\mathrm{a}}$ & clove-like [5] [3] \\
\hline 4-vinylguaiacol & $188 \pm 49$ & $6 \pm 0.4$ & $330 \pm 90$ & $2890 \pm 977$ & $130[5] ; 1100[8]^{\mathrm{a}}$ & phenolic, bitter [4]; pharmaceutic-spicy [12] \\
\hline 4-vinylphenol & - & $6 \pm 1$ & $23 \pm 5$ & $637 \pm 298$ & $180[5]^{\mathrm{a}}$ & stramonium [5]; pharmaceutic [12] \\
\hline acetovanillone & $86 \pm 38$ & $18 \pm 3$ & - & $50 \pm 22$ & $1000[6]^{\mathrm{a}}$ & - \\
\hline zingerone & $37 \pm 16$ & $12 \pm 4$ & - & $282 \pm 91$ & - & - \\
\hline 3,4,5-trimethoxyphenol & - & $6 \pm 1$ & - & - & - & - \\
\hline Volatile fatty acids & & & & & & \\
\hline propanoic acid & - & - & $41 \pm 15$ & $33 \pm 10$ & - & - \\
\hline isobutyric acid & $540 \pm 189$ & $21 \pm 3$ & $98 \pm 19$ & - & $2300[8]^{\mathrm{a}}$ & Sweaty, bitter, vinegar [4] \\
\hline butyric acid & $408 \pm 154$ & $7 \pm 2$ & $688 \pm 187$ & $78 \pm 27$ & & \\
\hline 3-methyl +2 -methylbutyric acids & $728 \pm 242$ & $30 \pm 3$ & $242 \pm 63$ & $39 \pm 10$ & - & - \\
\hline hexanoic acid & $1047 \pm 390$ & $194 \pm 22$ & $732 \pm 148$ & $972 \pm 259$ & $420[8]^{\mathrm{a}}$ & fatty acid, oily, sweaty [4]; green [10] \\
\hline octanoic acid & $2091 \pm 797$ & $544 \pm 57$ & $918 \pm 219$ & $1047 \pm 325$ & $500[8]^{\mathrm{a}}$ & fatty acid, oily, sweaty [4] \\
\hline decanoic acid & $545 \pm 174$ & $97 \pm 10$ & $22 \pm 6$ & - & $1000^{\mathrm{a}}$ & Wax, rancid, soap [4] \\
\hline Lactones & & & & & & \\
\hline methoxyfuraneol & - & - & $48 \pm 10$ & - & - & - \\
\hline furaneol & - & - & $1180 \pm 282$ & - & $37[15]^{\mathrm{a}}$ & Caramel [3] \\
\hline$\gamma$-decalactone & - & $23 \pm 4$ & - & - & $1000[2]^{\mathrm{b}}$ & \\
\hline Sulfur compounds & & & & & & \\
\hline 2-methyltetrahydrothiophen-3-one & - & $20 \pm 2$ & - & - & - & \\
\hline 2-(methylthio)ethanol & - & - & $51 \pm 8$ & - & - & \\
\hline methionol & $65 \pm 21$ & $4 \pm 1$ & $510 \pm 116$ & - & - & \\
\hline Carbonyl compounds & & & & & & \\
\hline 6-methyl-5-hepten-2-one & - & - & - & $63 \pm 23$ & - & - \\
\hline benzaldehyde & - & $364 \pm 48$ & - & - & $5000[2]^{\mathrm{b}}$ & Almond [16] \\
\hline
\end{tabular}

[1] (Guth, 1997).

[2] (Moreno, Zea, Moyano, \& Medina, 2005).

[3] (Czerny et al., 2008).

[4] (Meilgaard, 1975). 
[5] (Boidron, Chatonnet, \& Pons, 1988).

[6] (Goméz-Míguez, Cacho, Ferreira, Vicario, \& Heredia, 2007).

[7] (Ferreira, Ortin, Escudero, Lopéz, \& Cacho, 2002).

[8] (Ferreira, López, \& Cacho, 2000).

[9] (Salo, 1970).

[10] (Escudero et al., 2004).

[11] (Guerche, Dauphin, Pons, Blancard, \& Darriet, 2006).

[12] (Boutou \& Chatonnet, 2007).

[13] (Ribéreau-Gayon et al., 2006).

[14] (Ribéreau-Gayon, Peynaud, Ribéreau-Gayon, \& Sudraud, 1975).

[15] (Kotseridis \& Baumes, 2000).

[16] (Étievant, 1991).

-not found.

a Threshold in model solution.

b Threshold in hydroalcoholic solution.

c Threshold in water.

2006), such as acetaldehyde, methyl acetate, ethyl acetate, 2methyl-1-propanol, 2-methyl-1-butanol, ethyl succinate and 2phenylethanol appeared in lower concentrations.

\subsubsection{Minor volatile compounds}

For a better understanding of fruit wine sensory profile, minor volatiles were analyzed for correlation with sensory data. Fifty seven compounds were identified among all fruit wines, presented in Table 8, where minor compounds were grouped according to chemical type. All fruit wines presented high content in volatile fatty acids, produced by yeast during lipid metabolism (Vilanova \& Oliveira, 2012), which contribute to wine aroma equilibrium despite generating fatty or sweat odors. Only hexanoic and octanoic acids were found above perception threshold, except for cherry wine, which can be related with high lipid content in the raw material. Most fruit wines also presented high content in volatile phenols, secondary metabolites of phenolic acids metabolism during fermentation. The production of volatile phenols is expected from the raw-materials used and the type of compounds produced dependent on fruit composition (Vilanova \& Oliveira, 2012). Banana wine presented high content in esters, all of them above the reported perception threshold, with special emphasis on isoamyl acetate. Mango wine also presented high ester content, namely of ethyl hexanoate and ethyl butyrate, possible contributors to the tropical aromas, along with isoamyl acetate (Meilgaard, 1975). Monoterpenic alcohols were also found in high concentrations in mango wine, $\alpha$-terpineol and linalol were found above the perception threshold. One of the distinguishing characteristics of mango wine was its considerable lactone content, approximately 32 folds higher than the perception threshold, due to high furaneol concentration. Monoterpenic alcohols were found in greater concentration and diversity in orange wine, namely linalool, geraniol, citronellol and terpinen-4-ol. Some of these relate to citric aroma descriptors

Table 9

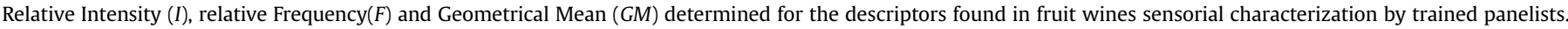

\begin{tabular}{|c|c|c|c|c|c|c|c|c|c|c|c|c|}
\hline \multirow[t]{2}{*}{ Descriptors } & \multicolumn{3}{|c|}{ Banana } & \multicolumn{3}{|c|}{ Mango } & \multicolumn{3}{|c|}{ Orange } & \multicolumn{3}{|c|}{ Cherry } \\
\hline & I \% & $\mathrm{F} \%$ & GM\% & I \% & $\mathrm{F} \%$ & GM \% & I \% & $\mathrm{F} \%$ & GM \% & I \% & $\mathrm{F} \%$ & GM \% \\
\hline \multicolumn{13}{|l|}{ Visual Analysis } \\
\hline Yellow & 52 & 100 & 72 & 0 & 0 & 0 & 0 & 0 & 0 & 0 & 0 & 0 \\
\hline Orange & 0 & 0 & 0 & 40 & 100 & 63 & 78 & 100 & 88 & 0 & 0 & 0 \\
\hline Cherry & 0 & 0 & 0 & 0 & 0 & 0 & 0 & 0 & 0 & 70 & 100 & 84 \\
\hline \multicolumn{13}{|c|}{ Olfactory Analysis } \\
\hline Intensity & 56 & 100 & 75 & 49 & 100 & 70 & 79 & 100 & 89 & 84 & 100 & 92 \\
\hline Quality & 57 & 100 & 76 & 79 & 100 & 89 & 57 & 100 & 76 & 78 & 100 & 88 \\
\hline Fruity & 0 & 0 & 0 & 33 & 57 & 44 & 0 & 0 & 0 & 44 & 71 & 56 \\
\hline Apple & 22 & 71 & 40 & 0 & 0 & 0 & 0 & 0 & 0 & 0 & 0 & 0 \\
\hline Citric & 19 & 71 & 37 & 22 & 57 & 36 & 71 & 100 & 85 & 0 & 0 & 0 \\
\hline Orange & 0 & 0 & 0 & 8 & 14 & 11 & 68 & 100 & 83 & 0 & 0 & 0 \\
\hline Mango & 0 & 0 & 0 & 32 & 71 & 48 & 0 & 0 & 0 & 0 & 0 & 0 \\
\hline Tropical & 0 & 0 & 0 & 57 & 10 & 76 & 0 & 0 & 0 & 0 & 0 & 0 \\
\hline Orange peel & 0 & 0 & 0 & 0 & 0 & 0 & 21 & 43 & 30 & 0 & 0 & 0 \\
\hline Cherry & 0 & 0 & 0 & 0 & 0 & 0 & 0 & 0 & 0 & 75 & 100 & 86 \\
\hline Dry fruit & 10 & 29 & 17 & 0 & 0 & 0 & 0 & 0 & 0 & 0 & 0 & 0 \\
\hline Banana & 13 & 57 & 27 & 0 & 0 & 0 & 0 & 0 & 0 & 0 & 0 & 0 \\
\hline Vegetal & 0 & 0 & 0 & 0 & 0 & 0 & 10 & 43 & 20 & 0 & 0 & 0 \\
\hline Red fruit & 0 & 0 & 0 & 0 & 0 & 0 & 0 & 0 & 0 & 37 & 71 & 51 \\
\hline Vanilla & 0 & 0 & 0 & 0 & 0 & 0 & 0 & 0 & 0 & 22 & 43 & 31 \\
\hline Caramel & 0 & 0 & 0 & 0 & 0 & 0 & 0 & 0 & 0 & 16 & 43 & 26 \\
\hline \multicolumn{13}{|c|}{ Gustatory analysis } \\
\hline Quality & 46 & 100 & 68 & 54.0 & 100 & 74 & 57 & 100 & 76 & 62 & 100 & 79 \\
\hline Sweet & 3 & 14 & 7 & 8 & 29 & 15 & 8 & 43 & 18 & 6 & 29 & 14 \\
\hline Salt & 3 & 14 & 7 & 3 & 29 & 10 & 2 & 29 & 7 & 2 & 14 & 5 \\
\hline Acid & 52 & 100 & 72 & 25 & 100 & 50 & 64 & 100 & 80 & 81 & 100 & 90 \\
\hline Bitter & 22 & 100 & 47 & 38 & 100 & 62 & 79 & 100 & 89 & 52 & 100 & 72 \\
\hline Body & 35 & 100 & 59 & 54 & 100 & 74 & 38 & 100 & 62 & 46 & 100 & 68 \\
\hline Persistence & 29 & 100 & 54 & 33 & 100 & 58 & 22 & 100 & 47 & 41 & 86 & 60 \\
\hline Astringency & 3 & 43 & 12 & 5 & 29 & 12 & 13 & 57 & 27 & 10 & 57 & 23 \\
\hline Global Value & 48 & 100 & 69 & 54 & 100 & 74 & 56 & 100 & 75 & 75 & 100 & 86 \\
\hline
\end{tabular}




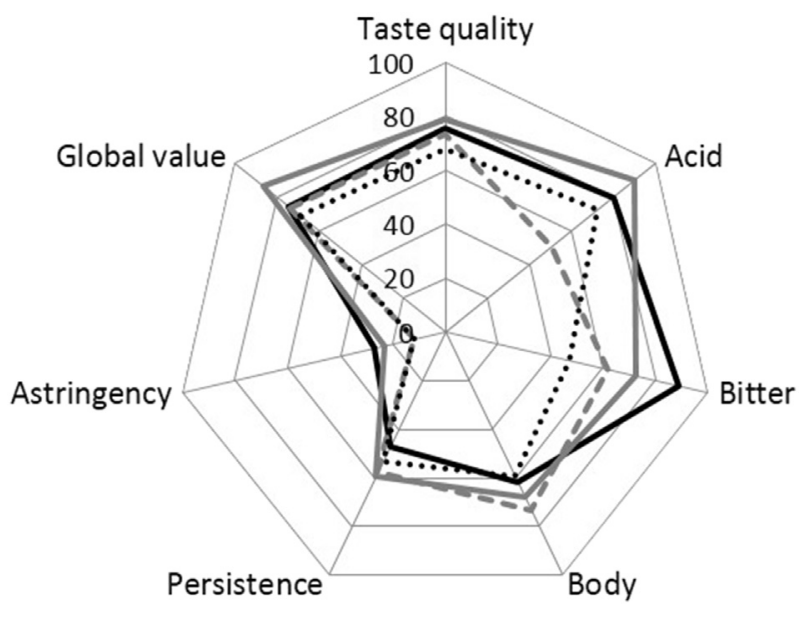

Fig. 2. Gustatory profile of fruit wines obtained from geometric mean (GM) of descriptors for (-) Orange, (---) Mango, (....) Banana and (-) Cherry, as measured by trained panelists.

and are expected from orange fruit. Cherry wine, also showed distinctive characteristics, namely higher ester diversity, with ethyl butyrate, isoamyl acetate, ethyl octanoate and ethyl hexanoate above perception thresholds. It also presented a much lower content in volatile fatty acids than the other fruit wines, and characteristic content of C13-norisoprenoids. Overall, fruit wines showed high concentrations of aroma active compounds, coherent with previous works (Reddy \& Reddy, 2009; Santos et al., 2013; Sun et al., 2013). The use of fruit concentrates and the optimal conditions determined are feasible for the production of fruit wines with satisfactory and characteristic volatile composition.

\subsubsection{Sensory analysis}

In order to correlate and complement analytical data and further assess organoleptic quality of fruit wines, a sensory evaluation was carried out. Table 9 shows the sensory descriptors identified in the samples and their correspondent means of relative frequency $(F)$ and intensity $(I)$ obtained by the tasting panelists.

The most characteristic olfactory descriptor for each fruit wine was: apple for banana $(G M=40 \%)$, tropical for mango $(G M=76 \%)$, citric for orange $(G M=85 \%)$ and cherry for cherry $(G M=86 \%)$. Esters with apple and tropical descriptors were found in banana and mango, and monoterpenic alcohols with citric descriptors were found in orange, which can be directly related to panelist's evaluation. From gustatory analysis, the highest GM for acidity were found for orange and cherry wines, and the lowest for banana wine. Acidity described in the gustatory evaluation for orange and cherry is directly supported by the higher organic acid concentrations quantified in these wines. Cherry wine was the most valued by the tasters and banana wine the one least preferred. Fig. 2 highlights the main fruit wine characteristics, with acidity, bitterness and body as the dominant features in the gustatory evaluation. However, fruit wines showed very distinguished aromatic features as seen in Fig. 3. Overall value and quality of fruit wines was around $70 \%-80 \%$, reinforcing alcoholic fermentation on generating added-value fruit products. Finally, PLSR2 analysis was performed taking into account the volatile families analyzed and sensory descriptors (\%GM), as presented in Fig. 4. The first PLSR2 was performed to relate aroma descriptors with volatile compounds (Fig. 4a). The biplot explained $75 \%$ of the variation. According to the loading weight, high correlations (more than 90\%) were found among dry fruit descriptors and banana with fatty acid compounds. Mango, and tropical were mainly predicted by sulphur compounds. Citric and orange were correlated with C6-alcohols and monoterpenic alcohols and a)

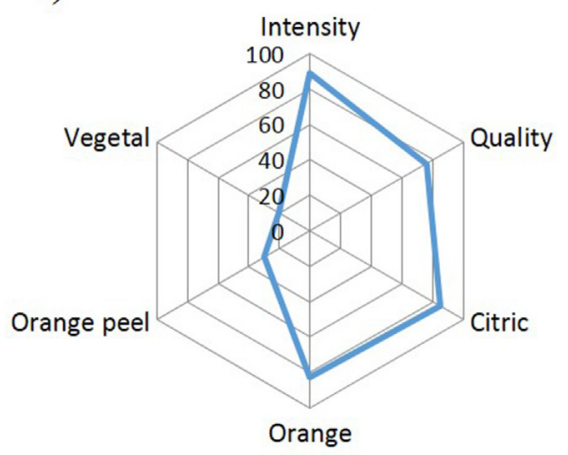

c)

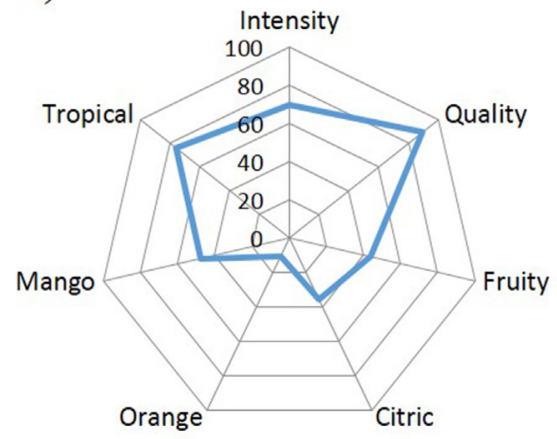

b)

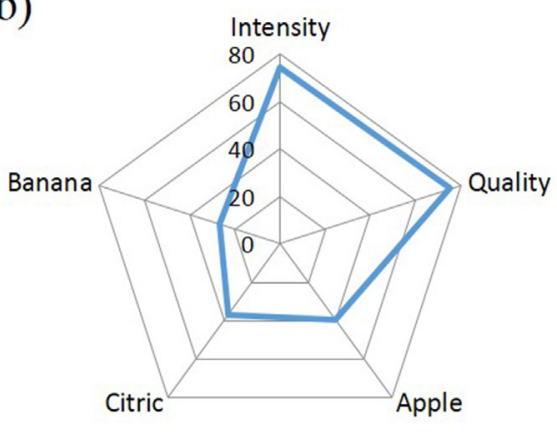

d)

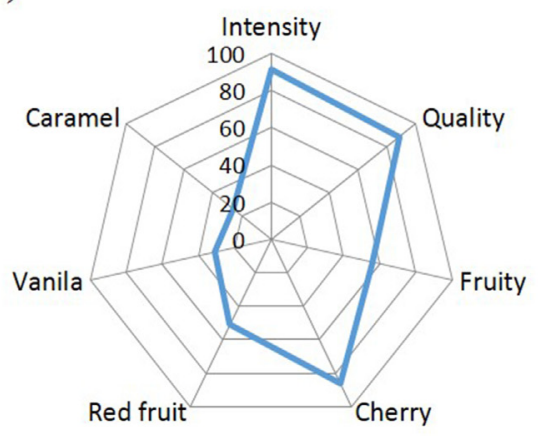

Fig. 3. Aroma profile, measured by trained panelists of: a) orange, b) banana, c) mango and d) cherry wines, obtained from geometric mean (GM) of the main descriptors. 


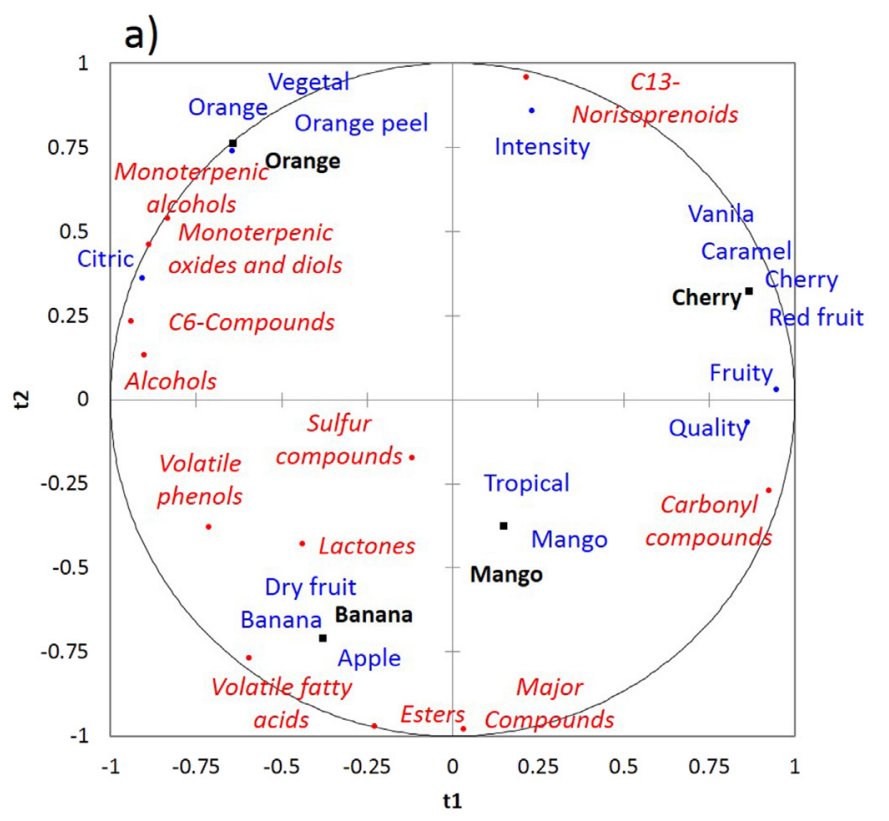

b)

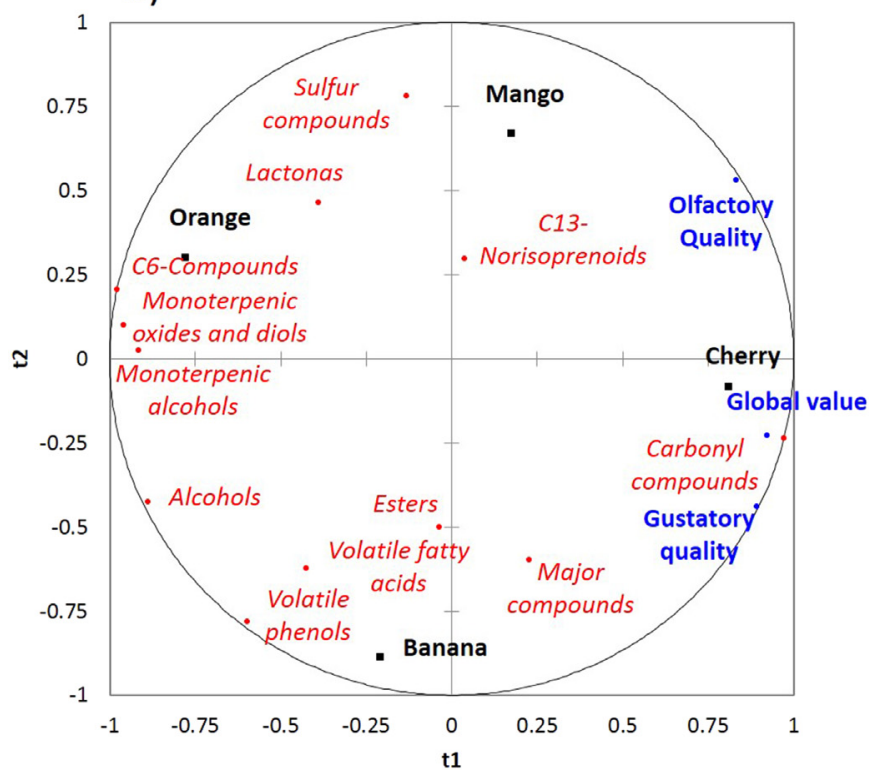

Fig. 4. Partial Least Square Regression (PLSR2) between volatile families and a) sensory aroma descriptors or b) olfactory and gustatory quality and global value.

oxides. Correlation between sensory perception and chemical composition in fruit wines is in good agreement with descriptors reported for each fruit, and furthermore provides information about the contribution of non-described minor volatiles for aroma. Another PLSR2 was performed to relate volatiles with the global value and olfactory and gustatory quality (Fig. 4b), which were positively correlated with carbonyl compounds (gustatory quality $68 \%$, olfactory quality $97 \%$ and global value $96 \%$ ). The biplot explained $95.6 \%$ of the variation. The PLSR2 analysis provided an insight of the synergetic effect between volatiles and perceived descriptors. Thus, fruit wines aroma is a direct result of positive and negative effects of the volatile composition and the balance attained. Correlations established allow further tuning of the fermented fruit products, considering the subsequent desired product and application. Nevertheless, fruit wines produced were broadly accepted, demonstrating its viability as a wine grade product.

\section{Conclusions}

Four fruit wines were successfully produced from industrially processed fruit concentrates. Mathematical models and optimal conditions for ethanol production were determined leading to maximal ethanol concentration in the shortest fermentation time. Alcoholic fermentation did not affect significantly antioxidant activity and fruit wines showed the antioxidant activity expected when taking into account the corresponding raw materials. Fruit wines had good acceptance from trained panelists, demonstrating its suitability as food grade products. Chemical characterization was in good agreement with sensory data and the correlations established were of upmost importance to understand the variables involved in fruit wine acceptability.

\section{Acknowledgments}

Authors would like to acknowledge the financial funding of: FruitVinegarDRINK QREN Project (ref. 23209), Project "BioInd Biotechnology and Bioengineering for improved Industrial and Agro-Food processes, REF. NORTE-07-0124-FEDER-000028" Cofunded by the Programa Operacional Regional do Norte (ON.2 O Novo Norte), QREN, FEDER and the FCT Strategic Project Pest-OE/ EQB/LA0023/2013.

\section{Appendix A. Supplementary data}

Supplementary data related to this article can be found at http:// dx.doi.org/10.1016/j.lwt.2015.02.020.

\section{References}

Akubor, P., Obio, S., Nwadomere, K., \& Obiomah, E. (2003). Production and quality evaluation of banana wine. Plant Foods for Human Nutrition, 58, 1-6.

Artero, A., Artero, A., Tarín, J. J., \& Cano, A. (2015). The impact of moderate wine consumption on health. Maturitas, 80(1), 3-13.

Boidron, J., Chatonnet, P., \& Pons, M. (1988). Effect of wood aroma compounds of wine. Connaissance de la Vigne et du Vin, 22(4), 275-294.

Boutou, S., \& Chatonnet, P. (2007). Rapid headspace solid-phase microextraction/gas chromatography/mass spectrometric assay for the quantitative determination of some of the main odorants causing off-flavours in wine. Journal of Chromatography A, 1141(1), 1-9.

Caplice, E., \& Fitzgerald, G. F. (1999). Food fermentations: role of microrganisms in food production and preservation. International Journal of Food Microbiology, 50, 131-149.

Czerny, M., Christlbauer, M., Christlbauer, M., Fischer, A., Granvogl, M., Hammer, M., et al. (2008). Re-investigation on odor thresholds of key food aroma compounds and development of an aroma language based on odor qualities of defined aqueous odorant solutions. European Food Research and Technology, 228(2), $265-273$.

Escudero, A., Gogorza, B., Melús, M. A., Ortín, N., Cacho, J., \& Ferreira, V. (2004). Characterization of the aroma of a wine from Maccabeo. Key role played by compounds with low odor activity values. Journal of Agricultural and Food Chemistry, 47(8), 3303-3308.

Étievant, P. (1991). Volatile compounds in foods and beverages. In H. Maarse (Ed.), Wine (pp. 483-546). New York: Marcel Dekker.

Ferreira, V., López, R., \& Cacho, J. (2000). Quantitative determination of the odorants of young red wines from different grape varieties. Journal of the Science of Food and Agriculture, 80(11), 1659-1667.

Ferreira, V., Ortin, N., Escudero, A., Lopéz, R., \& Cacho, R. (2002). Chemical characterization of the aroma of Grenade rosé wines: aroma extract dilution analysis, quantitative determination and sensory reconstitution studies. Journal of Agricultural and Food Chemistry, 50(14), 4048-4054.

Fu, L., Xu, B.-T., Xu, X.-R., Gan, R.-Y., Zhang, Y., Xia, E.-Q., et al. (2011). Antioxidant capacities and total phenolic contents of 62 fruits. Food Chemistry, 129(2), $345-350$.

Goméz-Míguez, M., Cacho, J., Ferreira, V., Vicario, I., \& Heredia, F. (2007). Volatile components of Zalema white wines. Food Chemistry, 100(4), 1464-1473.

Guerche, S. L., Dauphin, B., Pons, M., Blancard, D., \& Darriet, P. (2006). Characterization of some mushroom and earthy off-odors microbially induced by the development of rot on grapes. Journal of Agricultural and Food Chemistry, 54(24), 9193-9200.

Gustavsson, J., Cederberg, C., Sonesson, U., Otterdijk, R. V., \& Meybeck, A. (2011). Global food losses and food waste, extent, causes and prevention. Rome: FAO. 
Guth, J. (1997). Quantitation and sensory studies of character impact odorants of different white wine varieties. Journal of Agricultural and Food Chemistry, 45(8), 3027-3032.

Isitua, C., \& Ibeth, I. (2010). Novel method of wine production from banana (Musa acuminata) and pineapple (Ananas comosus) wastes. African Journal of Biotechnology, 9(44), 7521-7524.

Kelebek, H., Selli, S., Canbas, A., \& Cabaroglu, T. (2009). HPLC determination of organic acids, sugars, phenolic compositions and antioxidant capacity of orange juice and orange wine made from a Turkish cv. Kozan. Microchemical Journal, 91(2), 187-192.

Koppes, L. L., Dekker, J. M., Hendriks, H. F., Bouter, L. M., \& Heine, R. J. (2005). Moderate alcohol consumption lowers the risk of type 2 diabetes: a metaanalysis of prospective observational studies. Diabetes Care, 28(3), 719-725.

Kotseridis, Y., \& Baumes, R. (2000). Identification of impact odorants in Bordeaux red grape juice, in the commercial yeast used for its fermentation, and in the produced wine. Journal of Agricultural and Food Chemistry, 48(2), 400-406.

Meilgaard, M. (1975). Flavor chemistry of beer part II: flavor and threshold of 239 aroma volatiles. MBAA Technical Quarterly, 12(3), 151-168.

Moreno, J., Zea, L., Moyano, L., \& Medina, M. (2005). Aroma compounds as marker of the changes in sherry wines subjected to biological ageing. Food Control, 16(4), 333-338.

Müller, L., Gnoyke, S., Popken, A. M., \& Bröhm, V. (2010). Antioxidant capacity and related parameters of different fruit formulations. LWT-Food Science and Technology, 43(6), 992-999.

Neafsey, E. J., \& Collins, M. A. (2011). Moderate alcohol consumption and cognitive risk. Neuropsychiatric Disease and Treatment, 7, 465-484.

OIV. (2014). International code of oenological practices. Paris: Organisation Internationale du Vigne et du Vin.
Reddy, L. V., \& Reddy, O. V. (2009). Production optimization and characterization of wine from Mango (Mangifera Indica Linn.). Natural Product Radiance, 8(4), 426-435.

Ribéreau-Gayon, P., Glories, Y., Maujean, A., \& Dubourdieu, D. (2006). Handbook of enology, the chemistry of wine: Stabilization and treatments. Wiley.

Ribéreau-Gayon, J., Peynaud, E., Ribéreau-Gayon, P., \& Sudraud, P. (1975). Traité d'Oenologie: Sciences et Techniques du Vin. Paris: Dunod.

Room, R., Babor, T., \& Rehm, J. (2005). Alcohol and public health. Lancet, 365(9458), 519-530.

Salo, P. (1970). Determining the odor thresholds for some compounds in alcoholic beverages. Journal of Food Science, 35(1), 95-99.

Santos, C. C., Duarte, W. F., Carreiro, S. C., \& Schwan, R. F. (2013). Inoculated fermentation of orange juice (Citrus sinensis $\mathrm{L}$ ) for a production of a citric fruit spirit. Journal of the Institute of Brewing, 119(4), 280-287.

Sun, S. Y., Che, C. Y., Sun, T. F., Lv, Z. Z., He, S. X., Gu, H. N., et al. (2013). Evaluation of sequential inoculation of Saccharomyces cerevisiae and Oenococcus oeni strains on the chemical and aromatic profiles of cherry wines. Food Chemistry, 138(4), 2233-2241.

Tucker, G. (1993). Introduction. In G. Seymour, J. Taylor, \& G. Tucker (Eds.), Biochemistry of fruit ripening (pp. 1-51). London: Chapman\&Hall.

Usenik, V., Fabcic, J., \& Stampar, F. (2007). Sugars, organic acids, phenolic composition and antioxidant activity of sweet cherry (Prunus avium L.). Food Chemistry, 107(1), 185-192.

Vilanova, M., \& Oliveira, J. M. (2012). Application of Gas chromatography on the evaluation of grape and wine aroma in Atlantic Viticulture (NW Iberian Peninsula). In Dr B. Salih (Ed.), Gas chromatography in plant science, wine technology, toxicology and some specific applications. InTech. 